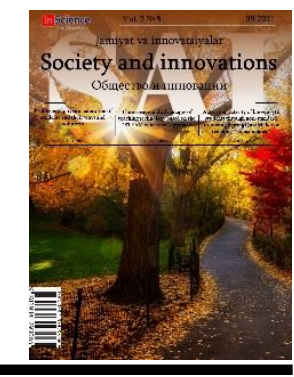

\title{
Particularities of movement skills manifestation by young gymnasts at initial training stage
}

\section{Djamshid UMAROV ${ }^{1}$}

Uzbek State University of Physical Education and Sport

\section{ARTICLE INFO}

Article history:

Received August 2021

Received in revised form

20 August 2021

Accepted 25 September 2021

Available online

25 October 2021

\footnotetext{
Keywords:

sensory period, movement skills and

abilities,

muscle strength,

special exercises,

inertial movement.
}

\section{ABSTRACT}

This article covers a comparative analysis of the indicators of the development of speed-strength qualities in the heterochronous way in the initial training of gymnasts aged 5-7 years. The results of the experiment gave us a possibility to determine the level of physical fitness of 5-7-year-old children, as well as confirmed that the physical qualities noted in them were elucidated by gender differences.

2181-1415/C) 2021 in Science LLC.

This is an open access article under the Attribution 4.0 International (CC BY 4.0) license (https://creativecommons.org/licenses/by/4.0/deed.ru)

Тайёргарликнинг

бошланғич

босқичида

ёш

гимнастикачиларнинг восита махоратининг намоён бўлиш хусусиятлари

\footnotetext{
Калит сўзлар:

сенситив (сезгир) давр, харакат қобилиятлари ва кўникмалари, мушакларнинг кучи, махсус машқлар, инерцион харакат
}

\begin{abstract}
АННОТАЦИЯ
Мақолада 5-7 ёшли гимнастикачиларни бошланғич тайёргарлик босқичида тезкорлик-куч сифатлари гетерохрон йўналишда ривожланиш кўрсаткичлари қиёсий тахлил қилинган. Ўтказилган тажриба натижалари 5-7 ёш болаларга хос жисмоний тайёргарлик даражасини аниқлаш имконини берди ва уларда қайд этилган жисмоний сифатлар жинслараро фарқ билан ифодаланганлигини тасдиқлаб берди.
\end{abstract}

\footnotetext{
${ }^{1}$ PhD., Associate Professor, Uzbek State University of Physical Education and Sport, Chirchik, Uzbekistan.
} 


\section{Особенности проявления двигательных навыков молодыми гимнастками на начальном этапе подготовки}

\author{
Ключевые слова: \\ сенситивный период, \\ двигательные умения и \\ навыки, \\ мышечная сила \\ специальные упражнения, \\ инерционное движение.
}

\begin{abstract}
АННОТАЦИЯ
В статье проводится сравнительный анализ показателей развития скоростно-силовых качеств в гетерохронном направлении на начальном этапе подготовки гимнасток 5-7 лет. Результаты эксперимента позволили определить уровень физической подготовленности детей в возрасте 5-7 лет и подтвердили, что отмеченные у них физические качества выражались гендерными различиями.
\end{abstract}

Some authors noted that physical skills development of preschool and school children, who involved in artistic gymnastics is accompanied by a number of particularities connected with body growth and its development $[1,3,5]$.

First of all, in this age, development of one physical skill make a positive effect on the growth of other skills, which is necessary to an integrated approach for development $[1,2,4]$.

Secondly, there is necessary to take into account that in the process of various functions body development, there are some sensitive periods when physical skills intensively increase. Other specialists $[1,6,7]$, think that pedagogical influences on physical skills development of young gymnasts are the most complete manifestation of those, whose growth is expressed in varying degrees of age development, who are engaged and especially important for shaping of movement skills.

All these indicators of muscle strength development are natural substrate and the main one for athlete's physical skills manifestation and realization.

Aim of the research. Experimentally substantiate the dynamics of speed-strength skills development of preschool and school children.

Task of the research. The level determination of speed-strength skills of young artistic gymnasts at the age of 5-7 years.

Research methodology. Questionnaires, pedagogical monitoring, special tests according to the program for special physical training; electrical registration of jumping exercises and its temporary parameters; pedagogical experiment; mathematical and statistical analysis of data obtained.

Test subjects. In the given experiment 90 preschool and school children, young artistic gymnasts are involved at the age of 5-7 years.

Research results. Polydynamometrical data allows to judge muscle strength potential only, which makes it possible to evaluate more precisely in the CFG (complex of force gradient) only in an act of action, or in extension.

In a practice, accompany by this, it is necessary to know how it is realized in practical tests and special exercises, actions that are structurally similar to the main competitive exercise.

A starting point of any development of sports results analysis should be the analysis of changes in individual movement skills. In order to determine the level of children 's physical skills, simple exercises were used, which do not require special skills and abilities, along with a control test program for special physical training. 
Testing analysis of speed-strength component of special physical training indicates about significant results improvement with taking account the age. There are two factors which are on the base of results improvement - age factors and the efficiency of gymnastics.

For example, 7-year-old girls already jump for $30 \mathrm{~cm}$ further than 5-year-old girls.

At this age boys improved their results relatively smaller just for $18 \mathrm{~cm}$.

However, boys at the age of 5 and 6-year-old have improved their results in shuttle running and long jump from floor (Table 1,2).

Table 1

\section{Results of girls' control tests $(\mathrm{n}=30)$}

\begin{tabular}{|l|c|c|c|c|c|c|}
\hline \multirow{2}{*}{ Tests } & \multicolumn{2}{|c|}{ 5 years old } & \multicolumn{2}{c|}{ 6 years old } & \multicolumn{2}{c|}{ 7 years old } \\
\cline { 2 - 7 } & Result & Score & Result & Score & Result & Score \\
\hline Shuttle running 2x10m, (sec) & 8,1 & 3,4 & 7,8 & 5,1 & 7,2 & 7,5 \\
\hline long jump from the spot, (cm) & 104,2 & 0,5 & 114,8 & 1,3 & 133,4 & 4,7 \\
\hline $\begin{array}{c}\text { Pull-ups till 900arm extension } \\
\text { (times) }\end{array}$ & 1,3 & 2,1 & 0,7 & 0,9 & 3,1 & 3,1 \\
\hline $\begin{array}{c}\text { Push-ups on two parallel } \\
\text { benches, (times) }\end{array}$ & 7,4 & 2,3 & 7,1 & 2,2 & 7,1 & 2,4 \\
\hline $\begin{array}{c}\text { Legs-ups to 90 in the position } \\
\text { of hanging (times) }\end{array}$ & 8,7 & 4,3 & 11,0 & 5,3 & 12,0 & 5,6 \\
\hline $\begin{array}{c}\text { Press keeping in the hang } \\
\text { position, (sec.) }\end{array}$ & 6,6 & 2,9 & 8,5 & 3,7 & 6,2 & 2,7 \\
\hline Flexibility assessment, (score) & & 6,9 & & 6,9 & & 7,7 \\
\hline $\begin{array}{c}\text { Summary scores for special } \\
\text { physical training }\end{array}$ & & 22,9 & & 25,3 & & 33,7 \\
\hline
\end{tabular}

Table 2

Results of boys' control tests $(n=30)$

\begin{tabular}{|c|c|c|c|c|c|c|}
\hline \multirow{2}{*}{ Tests } & \multicolumn{2}{|c|}{ 5 years old } & \multicolumn{2}{c|}{ 6 years old } & \multicolumn{2}{c|}{ 7 years old } \\
\cline { 2 - 7 } & Result & Score & Result & Score & Result & Score \\
\hline Shuttle running 2x10m, (sec) & 7,7 & 1,5 & 7,4 & 3,0 & 7,3 & 4,2 \\
\hline long jump from the spot, (cm) & 113 & 0,7 & 122,2 & 2,2 & 130,4 & 3,3 \\
\hline $\begin{array}{c}\text { Pull-ups till 90 } \text { arm extension } \\
\text { (times) }\end{array}$ & 2,5 & 2,0 & 2,1 & 1,8 & 2,9 & 2,2 \\
\hline $\begin{array}{c}\text { Push-ups on two parallel } \\
\text { benches, (times) }\end{array}$ & 8,2 & 3,2 & 7,7 & 3,0 & 12,5 & 5,2 \\
\hline $\begin{array}{c}\text { Legs-ups to 900 in the position } \\
\text { of hanging (times) }\end{array}$ & 9,0 & 5,3 & 11,8 & 6,2 & 11,4 & 6,3 \\
\hline $\begin{array}{c}\text { Press keeping in the hang } \\
\text { position, (sec.) }\end{array}$ & 5,2 & 2,5 & 5,8 & 2,6 & 3,1 & 1,5 \\
\hline Flexibility assessment, (score) & & 6,7 & & 6,7 & & 6,1 \\
\hline $\begin{array}{c}\text { Summary scores for special } \\
\text { physical training }\end{array}$ & & 21,9 & & 25,5 & & 28,7 \\
\hline
\end{tabular}


Evaluating the level of speed-strength performance of young gymnasts, it is necessary to compare the results in long jump from the spot with the average result shown by preschool and school children who do not do any sports.

Data in third Table show that children who do not do any sports are slightly concede in this indicator to their peers who do gymnastics.

Table 3

\section{Average indicators in long jump from the spot at 5-6 years old gymnasts and children who} do not do any sports $(\overline{\mathrm{x}} \pm \delta)$

\begin{tabular}{|c|c|c|c|c|}
\hline \multirow{2}{*}{ Age } & \multicolumn{2}{|c|}{ Girls } & \multicolumn{2}{c|}{ Boys } \\
\cline { 2 - 5 } & Gymnasts & $\begin{array}{c}\text { Do not do any } \\
\text { sports }\end{array}$ & Gymnasts & $\begin{array}{c}\text { Do not do any } \\
\text { sports }\end{array}$ \\
\hline 5 years old & $104,2 \pm 11,4$ & $95 \pm 10,9$ & $112,9 \pm 10,9$ & $111 \pm 11,3$ \\
\hline 6 years old & $114,7 \pm 11,6$ & $111 \pm 12,3$ & $122,2 \pm 12,8$ & $116 \pm 12,8$ \\
\hline
\end{tabular}

Data analyzing of strength exercises testing should be noted that many trainees first encountered this kind of exercises (push-ups on parallel benches, press keeping in the hanging, etc.) and, the first measurement results were extremely low.

However, even the first tests data indicate gender differences in young gymnasts.

In pull-ups and push-ups, 5-6 year old boys perform better than girls.

However, 7 year-old girls performed better in press keeping in hanging and pushups.

In several cases, although this is not statistically significant, 5 year-old gymnasts indicated higher results than 6 year-olds in pull-ups, push-ups and press keeping (7 yearolds). Abovementioned demonstrate that they could do more intensive development dynamics.

The lack indicator of mobility in joints was recorded by the sum of mistakes deductions in 3 exercises (so called "bridge", forward bend from sit-ups and any legs-split).

Judging by assessments point scale, it can be noted that the indicators of flexibility, both in girls and boys are at a low level. But there is a tendency towards the advantage of the flexibility development and mobility in girls joints.

Muscle's ability with instantaneous stretch is significant tension and subsequent rapid, powerful contraction underlies repulsion in all jumps.

The electrical registration of jumps temporal parameters makes it possible to assess the level of speed-strength skills manifestation, in particular, jumping skills, by the takingoff time from the support and flight time.

When the gymnast is repulsed from the contact, after the cushioning phase (when the muscles work in a concede mode), follows the actual repulsion phase, then the muscles, overcome the inertial movement of the body weight, begin to contract, communicating the system of movement from the contact.

Data obtained indicate age-related fluctuations in jumping temporal parameters. Both 5 year-old boys and girls have the same repulsion reaction from the contact. However, girls demonstrate a faster repulsion time in comparison with boys at the age of 6-7 years (Table 4) 
Electrical registration of jumps temporal parameters of young gymnasts aged 5-7 years $(\overline{\mathrm{x}} \pm \delta)$

\begin{tabular}{|c|c|c|c|c|}
\hline Age & $\begin{array}{c}\text { Repulsion time } \\
\text { (ml/sec.) }\end{array}$ & P & $\begin{array}{c}\text { Flight time, } \\
\text { (ml/sec.) }\end{array}$ & P \\
\hline \multicolumn{5}{|c|}{ Girls } \\
\hline 5 year & $0,210 \pm 0,038$ & - & $0,346 \pm 0,021$ & $>0,05$ \\
6 year & $0,183 \pm 0,032$ & $>0,05$ & $0,370 \pm 0,036$ & $<0,05$ \\
7 year & $0,177 \pm 0,038$ & $<0,05$ & $0,391 \pm 0,035$ & \\
\hline \multicolumn{5}{|c|}{ Boys } \\
\hline 5 year & $0,210 \pm 0,051$ & $<0,05$ & $0,333 \pm 0,033$ & - \\
6 year & $0,215 \pm 0,063$ & $<0,05$ & $0,384 \pm 0,049$ & $>0,05$ \\
7 year & $0,198 \pm 0,041$ & $0,382 \pm 0,031$ & $<0,05$ \\
\hline
\end{tabular}

Results of boys' repulsion from the contact year after year change little but have a tendency to improve. The second parameter (flight time), results' improvement is observed according to the age. For girls during two years (from 5 to 7 years) the indicator increases by $13.0 \%$, for boys the greatest increase (15.3\%) is noted from 5 to 6 years. However, flight time of 7 years olds is similar to 6 years old.

Jumps temporal parameters analysis allows concluding that at this age in girls the jumping ability development is the most successful. There are results increasing in all indicators in the age aspect.

In order to determine the leg muscles explosive strength was taken jump up from the spot according to the method of Abalakov (Table 5).

Table 5

\section{Jump-up from the spot results at young gymnasts}

\begin{tabular}{|c|c|c|c|c|c|}
\hline \multirow{2}{*}{ Indicators } & \multirow{2}{*}{ Age } & \multicolumn{2}{|c|}{ Girls } & \multicolumn{2}{c|}{ Boys } \\
\cline { 3 - 5 } & & $(\overline{\mathrm{x}} \pm \boldsymbol{\delta})$ & $\mathrm{t}$ & $(\overline{\mathrm{x}} \pm \boldsymbol{\delta})$ & $\mathrm{t}$ \\
\hline \multirow{2}{*}{ Jump-up from the spot without } & 5 years & $28,3 \pm 4,2$ & - & $27,6 \pm 3,7$ & - \\
hands swing (cm) & 6 years & $33,1 \pm 3,8$ & 7,0 & $31,1 \pm 3,7$ & 4,5 \\
& 7 years & $35,0 \pm 5,1$ & 1,9 & $35,9 \pm 5,1$ & 4,6 \\
\hline \multirow{2}{*}{ Jump-up from the spot with } & 5 years & $30,7 \pm 4,3$ & - & $30,1 \pm 4,2$ & - \\
hands swing (cm) & 6 years & $35,5 \pm 4,4$ & 6,5 & $34,6 \pm 3,9$ & 5,2 \\
\hline
\end{tabular}

There is a fact that in repulsion, 6 year-old boys (11.2\%) and 7 year-old girls (10.3\%) realizing much better the exercises so called jump-up from the spot with hands swing. At the same time, 7 year-old boys and 6 year-old girls use this potential by $4.2 \%$ and $7.3 \%$.

Some features and relationships were established between the results of electrical registration of jumps time parameters and jumps up from the spot due to correlation analysis. 
For example: has been found the relationship between the results of repulsion time from a contact and jumping up from a spot without hands swing $(r=0.711)$, in 5year-old boys, remains at the age of 7 (at 6 years $r=0.740$, at 7 years $r=0.505$ )

A close relationship was also revealed between the flight time indicator and the results of jumps-up from the spot: at the age of 5 with the result of a jump-up from the spot with hands swing - $r=0.763$, at 6 and 7 years old with the results of a jump-up from the spot without hands swing $(r=0.542$ and 0.666$)$.

As a result, the data of the first control tests made it possible to determine the level of physical performance of 5-7 years old children, to reveal the presence of gender differences in physical skills manifestation.

Progressively improvement of the results in tests for special physical training was found according to the age in the tests characterizing speed-strength performance only.

For example, in speed-strength skills development, there is a superiority of 5-6 yearold boys over girls and vice versa in flexibility development.

In the research process, was found a decreasing of growth rate in special physical training results at 6 and 7 year-old gymnasts compared to 5 year-old gymnasts, particularly in strength exercises, which indicates for the scientific verification of the issue of connection with the course of the first growth during this period and what should be done to correct training methods and means of young gymnasts at initial training stage.

\section{REFERENCES:}

1. Gaverdovskiy Y.K., Lisitskaya T.S., Rozin E.Y., Smolevskiy V.M., Artistic Gymnastics (men and women) // An exemplary sports training program for Youth sports schools, Junior Sports Schools, school of higher sportsmanship M.: Soviet Sport, 2005 - P. 420.

2. Matveev L.P. Theory and methodology of physical culture (general foundations of the theory and methodology of physical education: theoretical and methodological aspects of sports and professionally applied forms of physical culture). M.: Physical culture and sport, 1991. - P. 543.

3. Rozin E.Y. General foundations of sports orientation, selection and forecasting in gymnastics. Gymnastics 1996. - No. 1. - PP. 19-25.

4. Rozin E.Y. Physical training of gymnasts. // Tutorial. M.: 2002. - P. 137.

5. The system of training young gymnasts. // Methodical manual. Compiled by Shlemin A.M., Petrov P.K. - M.: 1997. - P. 178.

6. Umarov D.X. Development technology of physical skills of young gymnasts in preparation. Diss... PhD. T.: 2007. - P. 187.

7. Umarov M.N., Eshtaev A.K. Planning and distribution of funds for training gymnasts at initial training stage. // Tutorial. T.: 2004. - P. 154. 